University of Nebraska - Lincoln

DigitalCommons@University of Nebraska - Lincoln

USDA Wildlife Services - Staff Publications

U.S. Department of Agriculture: Animal and Plant Health Inspection Service

$7-1-2021$

\title{
Economic Losses of Catfish to Avian Predation: A Case Report
}

\author{
Ganesh Kumar \\ Mississippi State University, gkk27@msstate.edu \\ Shraddha Hegde \\ Mississippi State University \\ David Wise \\ Mississippi State University \\ Charles Mischke \\ Mississippi State University \\ Brian Dorr \\ USDA APHIS, NWRC
}

Follow this and additional works at: https://digitalcommons.unl.edu/icwdm_usdanwrc

Part of the Natural Resources and Conservation Commons, Natural Resources Management and Policy Commons, Other Environmental Sciences Commons, Other Veterinary Medicine Commons, Population Biology Commons, Terrestrial and Aquatic Ecology Commons, Veterinary Infectious Diseases Commons, Veterinary Microbiology and Immunobiology Commons, Veterinary Preventive Medicine, Epidemiology, and Public Health Commons, and the Zoology Commons

Kumar, Ganesh; Hegde, Shraddha; Wise, David; Mischke, Charles; and Dorr, Brian, "Economic Losses of Catfish to Avian Predation: A Case Report" (2021). USDA Wildlife Services - Staff Publications. 2491. https://digitalcommons.unl.edu/icwdm_usdanwrc/2491

This Article is brought to you for free and open access by the U.S. Department of Agriculture: Animal and Plant Health Inspection Service at DigitalCommons@University of Nebraska - Lincoln. It has been accepted for inclusion in USDA Wildlife Services - Staff Publications by an authorized administrator of DigitalCommons@University of Nebraska - Lincoln. 


\title{
Economic Losses of Catfish to Avian Predation: A Case Report
}

\author{
Ganesh Kumar,* (D) Shraddha Hegde, (D) David Wise, (D) and Charles Mischke \\ Thad Cochran National Warmwater Aquaculture Center, Mississippi State University, Post Office Box 197, Stoneville, \\ Mississippi 38776, USA
}

\section{Brian Dorr}

U.S. Department of Agriculture, Animal and Plant Health Inspection Service, Wildlife Services, National Wildlife

Research Center, Mississippi Field Station, Post Office Drawer 6099, Mississippi State University, Mississippi 39762, $U S A$

\begin{abstract}
Avian predation in catfish aquaculture has been a persistent issue throughout the history of the industry, and as production has expanded predation from piscivorous birds has intensified. Catfish ponds in the Mississippi River delta (in the Mississippi migratory flyway) provide a constant and readily accessible supply of forage for birds. Intensive foraging by fish-eating birds has led to a specific regulatory policy and numerous on-farm and regional management efforts. However, in 2016, legal challenges lead to recision of some federal policies and uncertainty as to allowable management, resulting in limitations on bird depredation. Estimating the extent of fish losses to avian predators is difficult, as loss estimates from farms are often confounded with disease- and management-related mortalities. This study details the reported losses to birds that were observed in commercial-scale catfish ponds at the Thad Cochran National Warmwater Aquaculture Center, Stoneville, Mississippi, during periods of limited bird management. The observed fish losses attributed to birds ranged from $33 \%$ to $95 \%$ loss in survival and potential yield losses of 4,396 to $\mathbf{8 , 8 8 9} \mathrm{lb} / \mathrm{acre}$, increasing production costs and decreasing net returns. Net economic losses when accounting for negative net returns and lost profits ranged from US\$3,518 to \$4,060/acre. Losses of this magnitude on commercial fish farms are economically detrimental, especially because catfish farms lack the compensatory economic relief programs that are available in other agriculture sectors. Roost dispersal activities that are organized by federal agencies and avoiding delays in issuing bird depredation permits are vital for mitigating this persistent and growing regulatory problem in the U.S. catfish industry.
\end{abstract}

Avian predation has been an issue throughout the history of catfish aquaculture in the southern United States. (Dorr and Taylor 2003; Dorr and Fielder 2017; Engle et al. 2020). Catfish operations, especially those that are located in the Mississippi River delta region of the Mississippi flyway, provide a constant and readily accessible supply of forage for birds. The most serious avian predators in the southeastern USA are the double-crested cormorant (DCCO) Phalacrocorax auritus, the great blue heron Ardea herodias, the American white pelican
(AWPE) Pelecanus erythrorhynchos, and the great egret Ardea alba (Stickley and Andrews 1989; Glahn and King 2004). All are native migratory birds that are protected under the Migratory Bird Treaty Act of 1918, limiting lethal control by producers (Engle 2003; Engle and Stone 2013). The population of avian predators, especially DCCO and the AWPE, has rapidly risen (Dorr et al. 2012a, 2012b, 2014a, 2014b; NABCI 2014) and now justifies greater management attention (DOI 2019). Growing bird predation on catfish farms is further worsened by

*Corresponding author: gkk27@msstate.edu

Received May 22, 2020; accepted July 1, 2020 
industry contraction of farming area (Hanson 2019) and intensified production (Tucker et al. 2014; Kumar and Engle 2017a, 2017b; Kumar et al. 2018, 2020).

Double-crested cormorants are common throughout North America and historically have been the primary avian predator on catfish operations in the southeastern USA (Glahn and King 2004). The DCCO migrates along the Mississippi River to and from the breeding grounds in the Upper Midwest and Canada to wintering sites in the lower Mississippi River valley. Aside from small resident breeding populations, the DCCO feed on catfish ponds in the greatest numbers in February and March during the annual migration (Dorr et al. 2012b). The most recent surveys estimate the North American population of DCCO at over 841,000 with about 548,000 migrating through the lower Mississippi valley (USFWS 2020).

Before 1990, the AWPE was not recognized as a major avian predator on commercial catfish farms, but over the past 30 years pelicans have become a source of significant economic losses in Mississippi, Arkansas, and Alabama (King 1995; King and Werner 2001; King et al. 2010; Wise et al. 2008). Information concerning population distribution and numbers is sparse. The eastern AWPE population follows a similar migratory route as the DCCO and is most common on farms in Mississippi, Alabama, and Arkansas during the late fall and winter months (November-April) when human activity on farms is minimal. This coupled with the nocturnal feeding habits of the AWPE make their management difficult (Glahn and King 2004). There are no current surveys estimating bird numbers, but in 1981 the eastern population was estimated to be $\sim 120,000$ birds. Birds typically forage in small flocks of $<50$ birds, but larger flocks foraging on catfish ponds of 250 birds are common, and as many as 2,000 pelicans have been observed on a typical catfish pond (King and Werner 2001). Each pelican is estimated to consume about $6.6 \mathrm{lb} \mathrm{fish} / \mathrm{d}$, and if left unharassed can decimate a pond population of catfish (Glahn and King 2004). More importantly, the AWPE is also a disease vector for the trematode Bolbophorous damnificus, which has a greater economic impact than losses resulting from simple fish predation (Wise et al. 2008). The economic impact on catfish aquaculture is difficult to assess, but predation and disease losses associated with the AWPE led to several farm closures in Mississippi and Louisiana (King and Werner 2001).

Many studies have attempted to quantify catfish losses to DCCO primarily through producer surveys, bioenergetic projections, or the results from simulated experimental conditions using captive birds (Stickley et al. 1992; Glahn and Brugger 1995; Glahn and Stickley 1995; Glahn et al. 2000, 2002; Glahn and Dorr 2002; Dorr et al. 2012a, 2012b, 2014a; Dorr and Engle 2015). These studies have suggested that DCCO consumed about $4 \%$ to $14 \%$ of the catfish pond biomass. Wywialowski (1999) estimated the national industrywide losses to piscivorous birds at US\$12 million in 1997. Bioenergetic modeling estimates that the average DCCO consumes $\approx 1.1 \mathrm{lb}$ fish/d, equivalent to $12-13$ fish/d (Glahn and Brugger 1995). Extrapolations from a controlled experimental predation study estimated that 30 DCCO could consume 22,000 catfish over $100 \mathrm{~d}$ of feeding and estimated the national industrywide economic impact at \$25 million (Glahn and Dorr 2002; Glahn and King 2004). Dorr et al. (2012a) more specifically attributed losses to DCCO predation in the Mississippi River delta alone at $\$ 6$ and $\$ 12$ million during 2000-2001 and 2003-2004, respectively.

Farmers spend considerable resources harassing birds from catfish operations in attempts to minimize their losses. A 2017-2018 industrywide study (Engle et al. 2020) found that catfish farmers spent an average of $\$ 281 /$ acre to harass birds, making bird-control costs one of the top five costs of raising catfish. The study also estimated the industrywide value of catfish losses to DCCO at \$47 million/year based on an improved method of fish loss estimation (Christie 2019). The cumulative effects of increased bird control costs ( $\$ 18$ million/year) and the value of the catfish lost to predation by DCCO caused substantial negative economic effects on catfish farms, averaging $\$ 65$ million/year (Engle et al. 2020). An accurate assessment of the economic losses that are associated with AWPE is not available, but the economic losses that are associated with trematode infestations are more widespread in the catfish industry. Depending on disease severity, trematode infections can cost farmers between $\$ 374$ and $\$ 1,060 / a c r e$ in food fish production (Wise et al. 2008). Such loss estimates demonstrate the need to develop effective bird-control strategies to minimize predation on catfish aquaculture operations.

Estimating the extent of fish losses from avian predators on commercial operations is difficult, as documented fish loss estimates are usually linked to disease ${ }^{1}$ - and/or management-related mortalities (Wise et al. 2004). Farmlevel research verification studies requesting catfish producers to quantify losses to birds in the absence of bird depredation are impractical. Efforts at predation simulation studies on small (0.02 ha) research ponds (Dorr and Engle 2015) have been informative but are limited by issues of scale and variation in production practices. Documenting the actual fish losses to birds on catfish farms in the absence of lethal controls can only be provided from documented losses in commercial-scale research ponds.

\footnotetext{
${ }^{1}$ Birds are also a link in catfish diseases such as trematodes (Wise et al. 2008) and act as zoomites for several major catfish diseases such as Edwardsiellosis, columnaris, and Aeromonas (Griffin et al. 2018; Cunningham et al. 2020), thus causing indirect economic losses that are difficult to quantify.
} 
This study details the impacts of fish-eating birds on two production studies conducted in commercial-scale experimental ponds that are located at the Thad Cochran National Warmwater Aquaculture Center (TCNWAC) during discrete production seasons from 2010 to 2012 and in 2017. Earlier economic studies involving bird predation accounted only for the value of fish lost to birds as foregone revenue. However, the true extent of economic loss on farms is captured through estimating lost profits (Hegde and Kumar 2019; Li et al. 2020; Asche et al., in press). Such estimations on farms are absent due to the difficulty of quantifying specific costs and returns (Engle et al. 2020). This paper discusses the economic losses from avian predation in the absence of lethal control on commercial-scale catfish research ponds that are managed at various stocking densities and management practices.

\section{METHODS}

The first case study (traditional multiple-batch ponds) documents fish losses to birds in traditional multiple-batch production during three continuous production seasons during 2010-2012 at the TCNWAC facility. The second case (intensively aerated ponds) investigated the economics of fish losses to DCCO in intensively aerated ponds. In both studies, nonlethal harassment techniques such as propane cannons, horns, and vehicles were only employed on a limited scale during production.

Traditional multiple-batch ponds. - The first case study documented fish losses to birds in traditional multiplebatch production during three continuous production seasons during 2010-2012 at the TCNWAC facility. The production trail was conducted on the northeast edge of the farm compound (Figure 1), a remote section of the facility that is near a wooded area with minimal traffic. Cormorants, egrets, pelicans, and herons were present in this section, but the most problematic piscivorous birds were the DCCO and AWPE. During the springs of 20102012, six, 7-acre ponds were stocked with Channel Catfish Ictalurus punctaus fingerlings averaging 0.04 to $0.1 \mathrm{lb} / \mathrm{fish}$ at 6,028-7,686 fish/acre as part of a yield verification of continuous production in multiple-batch ponds (Tucker et al. 1994). The ponds were fed and monitored according to accepted industry practices ( $\mathrm{Li}$ and Robinson 2012). Until 2010, production from this facility was typical, with bird sightings around the ponds being normal. However, by 2011 commercial catfish farms that are close to TCNWAC discontinued operations, resulting in increased bird-predation pressure on the facility. The species and estimated numbers of migratory birds that were sighted on the facility in the 2011 and 2012 seasons (William Rutland, Station Manager TCNWAC, unpublished data) were as follows: DCCO (8,000-10,000 birds; November-April), great egret (5,000-10,000 birds; August-November), AWPE (500-1,000 birds; March-April), and great blue heron (500 birds; all year). Nonlethal techniques had limited success and only moved birds to other areas of the operation or temporarily drove birds to a nearby loafing site.

All of the ponds were partially harvested to remove most of market-sized fish during fall (October-November) of each growing season, and annual production variables such as yield, average weight at harvest, total feed fed,

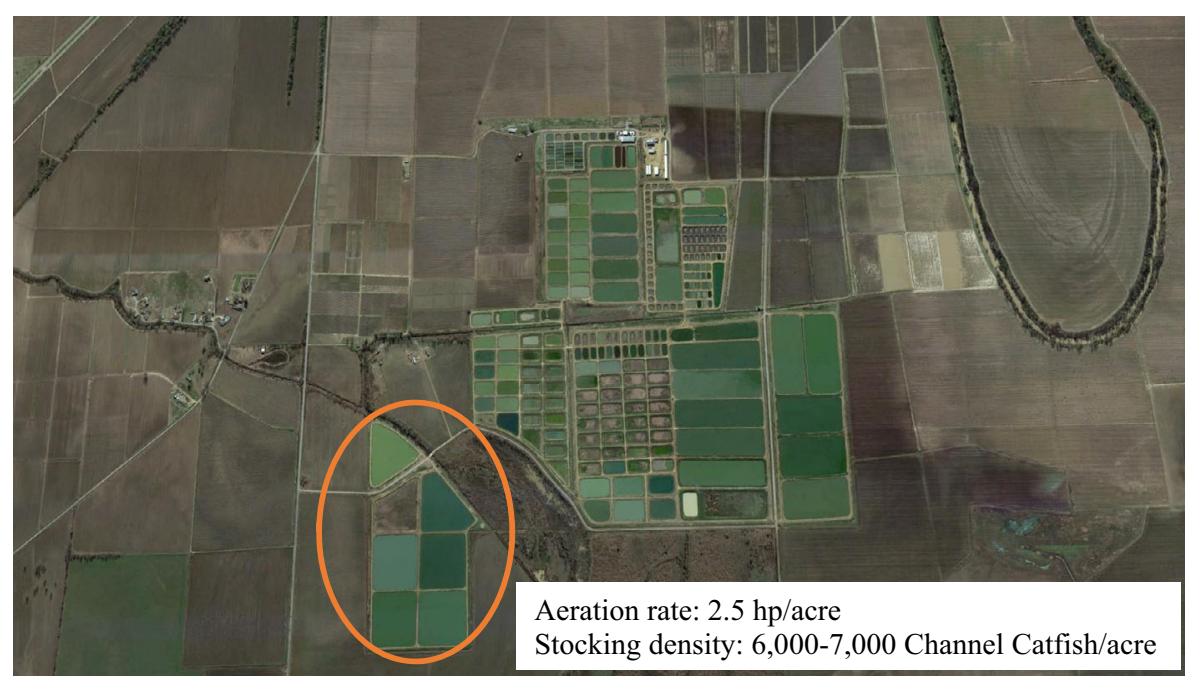

FIGURE 1. A layout of the 42-acre pond facility located away from the main research facility, 2010-2012. The traditional multiple batch production trials of 2010-2012 were conducted in this remote location. Photo credit: Google Earth. [Color figure can viewed at afsjournals.org.] 
and estimated ${ }^{2}$ feed conversion ratio (FCR) were recorded. The ponds were understocked with Channel Catfish fingerlings in the springs of 2011 and 2012 to simulate multiple-batch conditions. Complete harvest of all six ponds took place during December 2012, recording final production variables such as gross yield, net yield, weight gain, average weight at harvest, survival, total feed fed, and FCR. The annual production variables were compared across the three years of production.

Intensively aerated ponds. - The second case investigated the economics of fish losses to DCCO in intensively aerated ponds using hybrid catfish (o Blue Catfish I. furcatus $\times$ o Channel Catfish I. punctatus) fingerlings at relatively higher stocking densities $(10,000$ to 15,000 fingerlings/acre) and aeration rates ( $10 \mathrm{hp} / \mathrm{acre})$ during 2017. The study was intended to validate stocking and aeration rate recommendations in intensively aerated ponds. On January 31, 2017, three ponds (2.0 acre) were stocked at 10,391 fish/acre and three ponds (3.75 acre) were stocked at 15,570 fish/acre, using hybrid catfish fingerlings averaging $0.1 \mathrm{lb}$. Regulatory delay in the issue of bird permits in the fall of 2016 prevented the lethal taking of DCCO. Although nonlethal-harassment techniques such as pyrotechnics, propane cannons, horns, and vehicles were employed throughout the production season, the TCNWAC pond facility was inundated daily with habitually problematic DCCO in two replicate ponds in each density treatment. On average, there were between 30 and 50 birds in the affected ponds, but on weekends with the presence of a minimal workforce as many as 300 birds could be observed on the ponds. For unknown reasons, birds were not observed on the remaining replicates.

Following the natural DCCO migratory pattern, the birds migrated north in early April 2017 and no DCCOs were observed on the facility past this time. The ponds were seined to determine the extent of fish losses in ponds where DCCO were observed foraging. The seined fish were weighed, and count and weight measurements were used to estimate survival using the seinability coefficient ${ }^{3}$ (0.90) following Kumar and Engle (2010). The fish were immediately released back into the ponds, and the study continued through the remainder of the production season. The fish were fed once daily and managed according to standard industry protocols (Kumar and Engle 2017a; Kumar et al. 2019).

The fish in all six of the ponds were harvested using commercial methods after $204 \mathrm{~d}$. A subsample of $500 \mathrm{fish} /$ pond was weighed in small batches (20-25) to estimate average

\footnotetext{
${ }^{2}$ The FCRs are estimated as the ponds were not completely harvested until 2012.

${ }^{3}$ The seinability coefficient provides an estimate of the proportion of the fish population that is caught in one seine from a pond. Typically, hybrids have a high seinability coefficient of $\sim 90 \%$.
}

weight. Production variables such as gross yield, net yield, weight gain, average weight at harvest, growth rate, survival, total feed fed, and feed conversion ratio (FCR) were calculated. The averages of the production variables for the four ponds that were affected by birds were compared with those for the two ponds that were not affected by birds.

Economic analysis. - A standard enterprise budget analysis was employed to quantify the cost and returns of scenarios representing typical catfish production that is unaffected by birds relative to production that is affected by birds. Annual production budgets were developed for traditional multiple-batch systems for three production years across 2010-2012. Traditional multiple-batch production budgets (Kumar et al. 2020) were based on the average annual values provided in Table 1 and subjected to a breakeven price analysis. The breakeven price above variable costs (BEP/VC; $\$ / \mathrm{lb})$, total costs $(\mathrm{BEP} / \mathrm{TC} ; \$ / \mathrm{lb})$, and net returns (\$/acre) were calculated. The budgets from Kumar et al. (2020) were used as the basis for the economic analysis, with updated input use (feed, fingerlings, electricity use, and seining and harvesting costs). A 5-year average price of feed $(\$ 369 /$ ton $)$ and fish $(\$ 1.00 / 1 b)$ were used to capture the market variations that were observed in recent years (Hanson 2019). For the intensively aerated pond scenarios, the enterprise budgets were developed for a 5-acre pond (implied to be part of a 330-acre farm) using the average production variables from Table 2 . The additional investments that were required (Kumar et al. 2017a, 2019) for the construction and renovation of small 5-acre intensively aerated ponds were spread over the useful life of the investment (10 years). The annual depreciation costs were calculated by using a straight-line depreciation method. The interest on investment was charged at the rate of the opportunity cost of capital (10\%; Campo and Zuniga-Jara 2018) and added to the annual fixed costs in the budgets for each treatment.

The profitability of catfish production is heavily dependent on fish yield (Tucker et al. 1994; Engle 2003; Kumar et al. 2018, 2020; Engle et al. 2020). Hence the inability to produce sufficient yield from catfish ponds due to yield risk (Engle 2003, 2010) such as bird predation would not only increase the cost of production per unit (lb) of fish produced but also cause farmers to forego profits that could have been earned by harvesting fish under normal growing circumstances in the absence of yield risks (Hegde and Kumar 2019; Li et al. 2020). Therefore, calculations of economic loss from bird predation also consider foregone profits. This study quantified the net economic losses that were associated with bird predation scenarios by adding net returns and the associated foregone profits, with the latter accounted as (foregone) costs. Thus, the profits (\$/acre) received from a regular-production scenario in intensive and traditional multiple-batch production scenarios lacking bird-related losses were used as the foregone costs that were associated with scenarios that were affected by birds. 
TABLE 1. Production (mean \pm SD) and economic variables of traditional multiple-batch production ponds, 2010-2012. Production in 2010 was typical and is considered the base year of evaluation, while 2011 and 2012 had progressively higher observed bird depredation. Average values of treatment were used in the economic analysis because the study was not intended to quantify predation losses to birds. However, production variables such as gross yield and feeding rates were statistically significant between the treatments ( $t$-tests; $P \leq 0.05)$, justifying the use of actual treatment mean values in enterprise budgets.

\begin{tabular}{llccc}
\hline Variables & Units & 2010 & 2011 & 2012 \\
\hline & & Production variables & & 6 \\
Number of ponds & $n$ & 6 & 6 & $6,028 \pm 674$ \\
Stocking density & $n$ /acre & $7,686 \pm 1,123$ & $6,300 \pm 987$ & $0.035 \pm 0.01$ \\
Weight at stocking & lb/fish & $0.097 \pm 0.09$ & $0.069 \pm 0.07$ & $340 \pm 221$ \\
Gross yield & lb/acre & $6,445 \pm 3,296$ & $2,049 \pm 945$ & $1.4 \pm 0.2$ \\
Feeding rate & ton/acre & $4.7 \pm 2.2$ & $3.8 \pm 0.7$ & $22.4 \pm 2.0$ \\
FCR $^{\mathrm{a}}$ & ratio & $1.6 \pm 0.3$ & $4.7 \pm 2.6$ & 2,366 \\
& & Economic variables & 3,533 & 340 \\
Total costs & \$/acre & 4,411 & 2,049 & $-2,026$ \\
Total revenue & \$acre & 6,445 & $-1,484$ & 5.14 \\
Net returns & $\$ /$ acre & 2,034 & 1.42 & 6.96 \\
BEP/VC & \$/b & 0.59 & 1.72 & \\
BEP/TC & $\$ / l b$ & 0.68 & & \\
\hline
\end{tabular}

${ }^{a} \mathrm{FCR}$ values in 2010 and 2011 were estimated based on actual feed fed and harvested quantities of market-size fish ( $\left.\geq 1.25 \mathrm{lb}\right)$ from the continuous cropping that is typical in multiple-batch production.

TABLE 2. Production (mean $\pm \mathrm{SD})$ and economic variables of intensively aerated ponds in 2017 . The average values of treatment were used in the economic analysis because the study was not intended to quantify predation losses to birds. However, production variables such as gross yield, feeding rate, and survival were statistically different $(t$-test; $P \leq$ 0.05 ) between the treatments, justifying the use of actual treatment mean values in the economic analysis.

\begin{tabular}{llll}
\hline Variables & Units & Control ponds & \multicolumn{1}{c}{$\begin{array}{c}\text { Bird-affected } \\
\text { ponds }\end{array}$} \\
\hline $\begin{array}{c}\text { Production variables } \\
\text { Number of } \\
\text { ponds }\end{array}$ & $n \quad 2$ & 4 \\
$\begin{array}{c}\text { Stocking } \\
\text { density }\end{array}$ & $n /$ acre & $13,535 \pm 3,996$ & $12,703 \pm 2,864$ \\
Initial biomass & lb/acre & $1,396 \pm 247$ & $1,294 \pm 171$ \\
Weight at & lb/fish & $0.11 \pm 0.01$ & $0.10 \pm 0.01$ \\
stocking & & & \\
Gross yield & lb/acre & $16,845 \pm 6,415$ & $7,956 \pm 671$ \\
Harvest size & lb/fish & $1.56 \pm 0.13$ & $1.44 \pm 0.10$ \\
Survival & $\%$ & $79 \pm 1$ & $46 \pm 13$ \\
Feeding rate & ton/ & $16.9 \pm 6.4$ & $7.5 \pm 0.5$ \\
& acre & & \\
FCR & ratio & $2.2 \pm 0.1$ & $2.3 \pm 0.2$ \\
Growth rate & g/d & $3.56 \pm 0.15$ & $3.40 \pm 0.25$ \\
\multicolumn{4}{c}{ Economic variables } \\
Total costs & \$/acre & 14,236 & 9,123 \\
Total revenue & \$/acre & 16,845 & 7,956 \\
Net returns & \$/acre & 2,609 & $-1,167$ \\
BEP/VC & \$/lb & 0.71 & 0.87 \\
BEP/TC & \$/lb & 0.85 & 1.15 \\
\hline
\end{tabular}

\section{RESULTS}

\section{Traditional Multiple-Batch Ponds}

The gross production of Channel Catfish from traditional multiple-batch production from commercial-scale ponds at the TCNWAC facility was $6,445 \mathrm{lb} /$ acre in 2010 (Table 1). There was no apparent disease- or managementrelated fish losses in this section of the facility during the time of this study. However, the fish production from this 42 -acre section of ponds registered significant losses to birds in the subsequent 2 years, with fish production of 2,049 and $340 \mathrm{lb} /$ acre in 2011 and 2012, respectively. This reduction in gross yield in 2011 and 2012 corresponded to $68 \%$ and $95 \%$ reductions, respectfully, relative to production in 2010. The estimated FCRs in 2011 and 2012 were high relative to that in 2010 (Table 1).

The economic performance of catfish production from the TCNWAC facility indicated profitability in a typical year (2010) when it is devoid of excessive bird predation. The 2010 breakeven prices covering variable $(\$ 0.59 / 1 \mathrm{~b})$ and total costs $(\$ 0.68 / 1 \mathrm{~b})$ were lower than the fish prices, thus registering net returns of $\$ 2,034 /$ acre (Table 1). However, the resultant reduction in fish production due to bird predation in 2011 and 2012 increased the cost of production by $153 \%$ and $923 \%$, respectively. The net returns from fish production in 2011 and 2012 were negative $(-\$ 1,484$ and $-\$ 2,026 /$ acre, respectively), primarily due to the relatively higher revenue shortfall from 2010. The resultant economic losses due to bird predation after accounting for lost profit $(\$ 2,034 /$ acre $)$ were $-\$ 3,518$ and $-\$ 4,060 /$ acre in 2011 and 2012, respectively (Figure 2). 


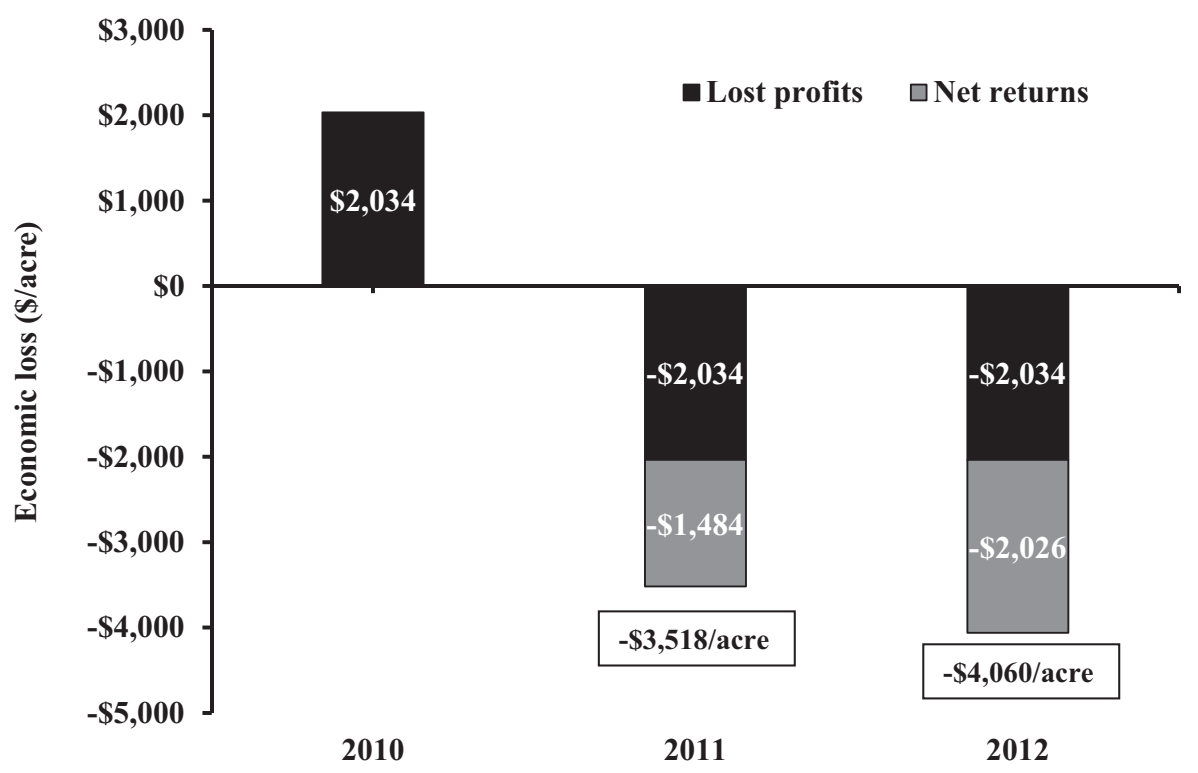

FIGURE 2. Economic losses (\$/acre) from bird depredation in traditional multiple-batch production ponds, 2010-2012.

\section{Intensively Aerated Ponds}

The gross yield and survival of the two intensively aerated ponds that were without bird predation were 16,845 $\mathrm{lb} / \mathrm{acre}$ and $79 \%$, respectively. In contrast, the gross production from the four intensively aerated ponds that were affected by birds was $53 \%$ less $(7,956 \mathrm{lb} / \mathrm{acre})$ than that from the ponds that were unaffected by bird predation (Table 2). Survival in the bird-affected ponds ranged from $31 \%$ to $62 \%$, while survival in the ponds that were unaffected by birds ranged from $78 \%$ to $79 \%$ (Figure 3A, B). The average survival $(46 \%)$ from the bird-affected ponds was $42 \%$ lower than survival from the unaffected ponds. Because no apparent disease or management-related fish losses were observed during the production cycle, the relative losses $(42 \%)$ were attributed to bird predation. The total feed consumption in the bird-affected ponds was reduced by $56 \%$ relative to that in ponds that were unaffected by birds. Such disparity in feed consumption was observed starting about week 5 of the study (Figure 4). This is typical, as commercial farmers report similar observations of predator presence negatively affecting catfish feeding activity. The mean weekly daily feeding rate of the ponds that were affected by birds permanently lagged behind that of the unaffected ponds. There were no significant differences in production variables such as feed conversion ratio, growth rate, and mean weight at harvest between the two treatments (Table 2).

The economic analysis suggested that although the total costs that were incurred in the bird-affected ponds $(\$ 9,123 /$ acre) were relatively less than those in the ponds that were unaffected by birds ( $\$ 14,236 /$ acre), the relative shortfall in revenue was high $(53 \%)$, primarily from reduced fish production due to bird predation (Table 2). This increased the cost of production (breakeven prices) covering the variable cost and total cost by $23 \%$ and $35 \%$, respectively, in the bird-affected ponds. The net returns from the ponds that were unaffected by birds were $\$ 2,609$ / acre, while returns from the bird-affected ponds were $-\$ 1,167 /$ acre. The resultant economic loss in the intensively aerated ponds due to bird predation, accounting for lost profit (\$2,609/acre), was $-\$ 3,776 /$ acre (Figure 5).

\section{DISCUSSION}

The consequences of increased avian predation have been a controversial subject in aquaculture and natural fisheries (Hatch 1995; Siegel-Causey 1999; Wires et al. 2001; Dorr et al. 2014a, 2014b; Dorr and Fielder 2017; Engle et al. 2020), and they have been a persistent economic issue in catfish farming. This is evidenced by legal challenges resulting in policy changes, leading to aspects of this research. Quantifying fish losses to birds is difficult on commercial catfish operations primarily because fish losses due to birds as reported by farms are confounded with disease- or management-related mortalities.

This work documents the production economic losses at the TCNWAC facility in two separate case studies. Although not designed to measure bird predation, this study documented fish losses from birds on a commercial scale in the absence of lethal control. The first case documented catfish losses to birds under traditional multiplebatch production in commercial-scale research ponds. Multiple-batch production is the most widely adopted commercial cropping strategy for raising Channel Catfish, 

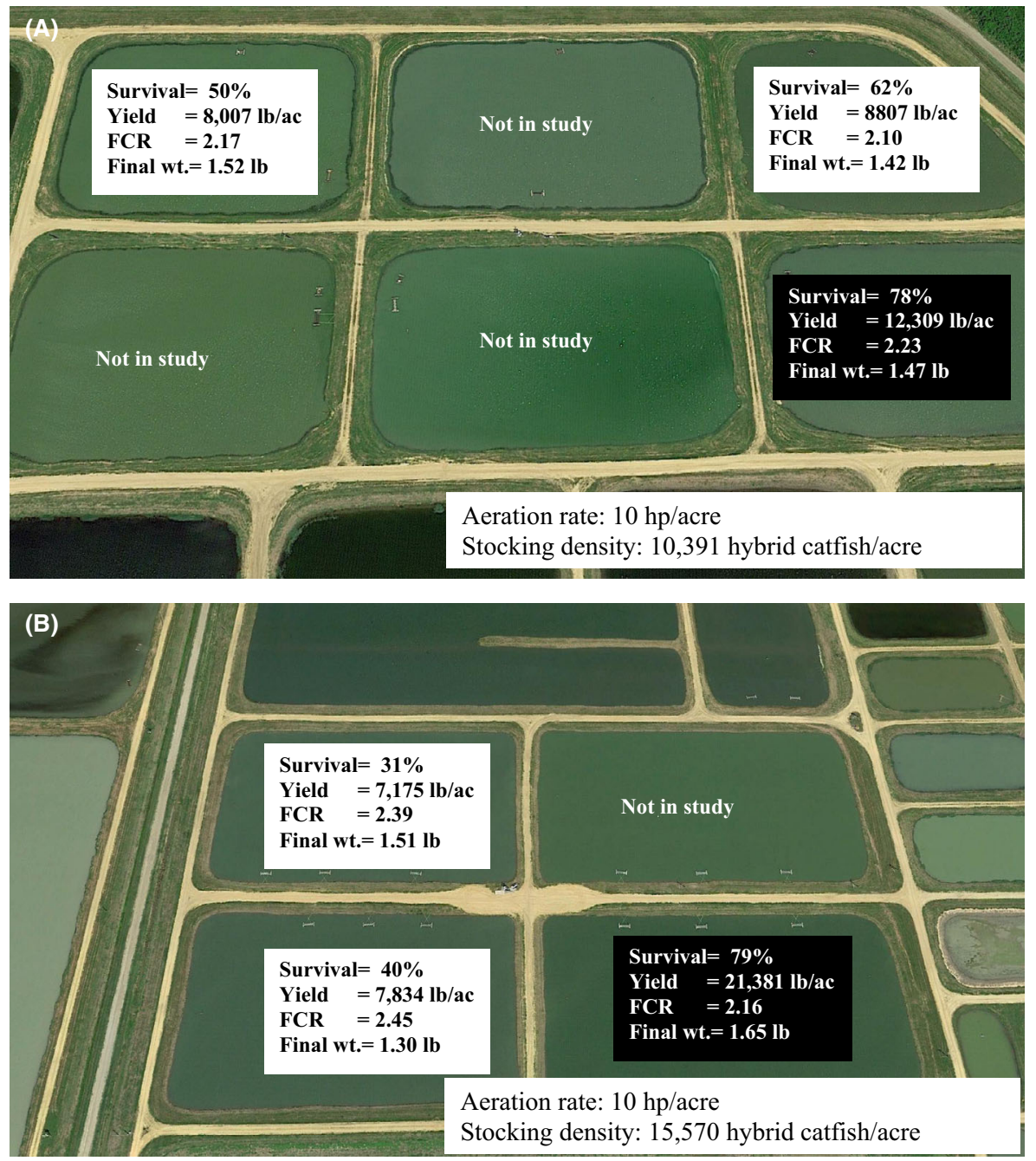

FIGURE 3. Layout and individual production variables of intensively aerated ponds stocked at (A) 10,391 hybrid catfish fingerlings/acre, 2017 and (B) 15,570 hybrid catfish fingerlings/acre, 2017. The dark box represents data from a pond that was unaffected by birds. Photo credit: Google Earth. [Color figure can viewed at afsjournals.org.]

with about $82 \%$ and $93 \%$ of farms adopting this practice on their farms in 2009 (USDA 2010) and 2015 (Kumar et al. 2020), respectively. Although less intensive, relatively lower profit margin (Engle et al. 2020; Kumar et al. 2020) from these production practices makes them sensitive to yield risks. The documented fish losses from this study were high, with $68 \%$ and $95 \%$ fish losses in 2011 and 2012, respectively, relative to the typical production of 6,445 lb/acre. Multiple species of common piscivorous birds such as DCCO, AWPE, the great blue heron, and the great egret were present on the ponds that were involved in the case study, but the observed fish losses were mainly attributed to the foraging activity of DCCO and AWPE.

Such extreme loss of yield resulted in a high cost of production of $\$ 1.72 / \mathrm{lb}$ and $\$ 6.96 / \mathrm{lb}$, respectively, in 2011 and 2012. The economic loss was $\$ 3,518$ and $\$ 4,060$ /acre in 2011 and 2012, respectively, when accounting for lost profits and net returns. In response to such extensive damage from fish-eating birds and the inability to effectively harass birds from remotely located ponds with less human activity, the section of ponds that was involved in this case study was withdrawn from further catfish production after 2012. Such events have also been anecdotally reported on commercial operations in remote locations near preferred bird-loafing sites and minimal management inputs. Most of the farms fitting these criteria are no longer in operation (Jimmy Avery, Mississippi State Extension Service, personal communication).

The second case study evaluated catfish predation losses exclusively to DCCO in intensively aerated ponds that were stocked with hybrid catfish fingerlings. This singlebatch production strategy for hybrid catfish grow out is being increasingly adopted by U.S. catfish producers, as 


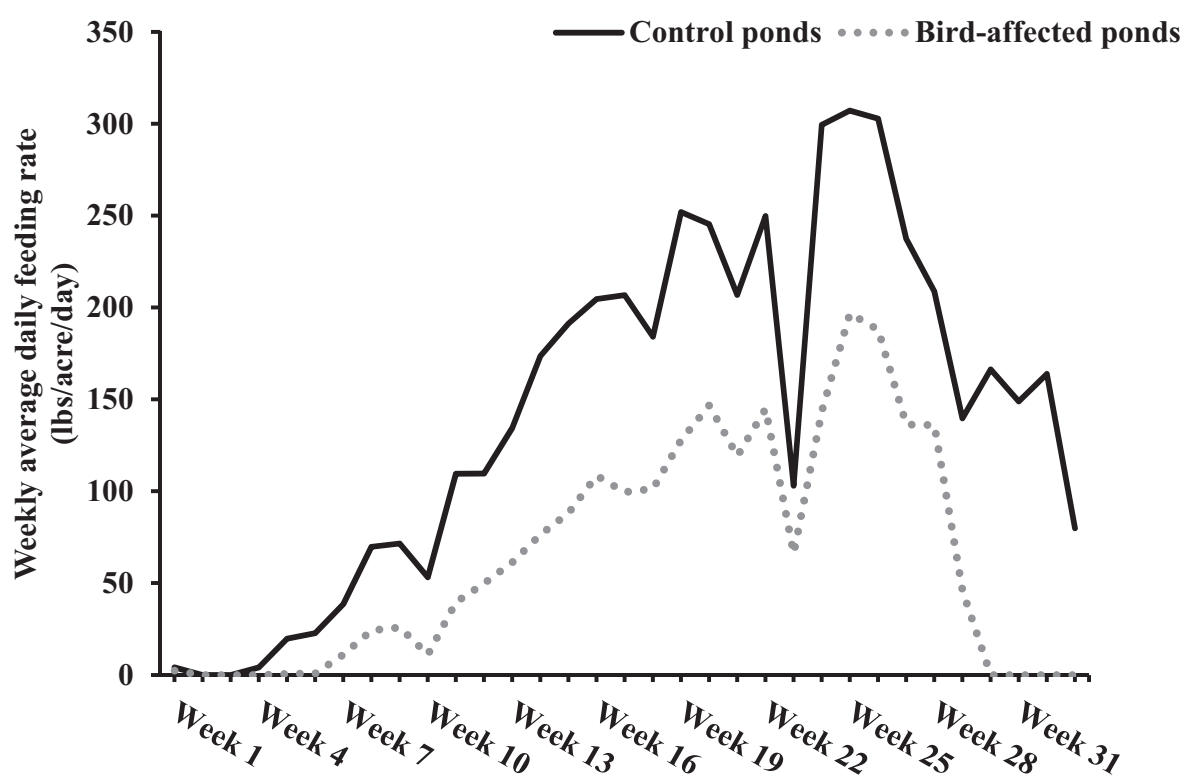

FIGURE 4. Weekly average daily feeding rate (lb/acre/d) of control and bird-affected intensively aerated ponds, 2017.

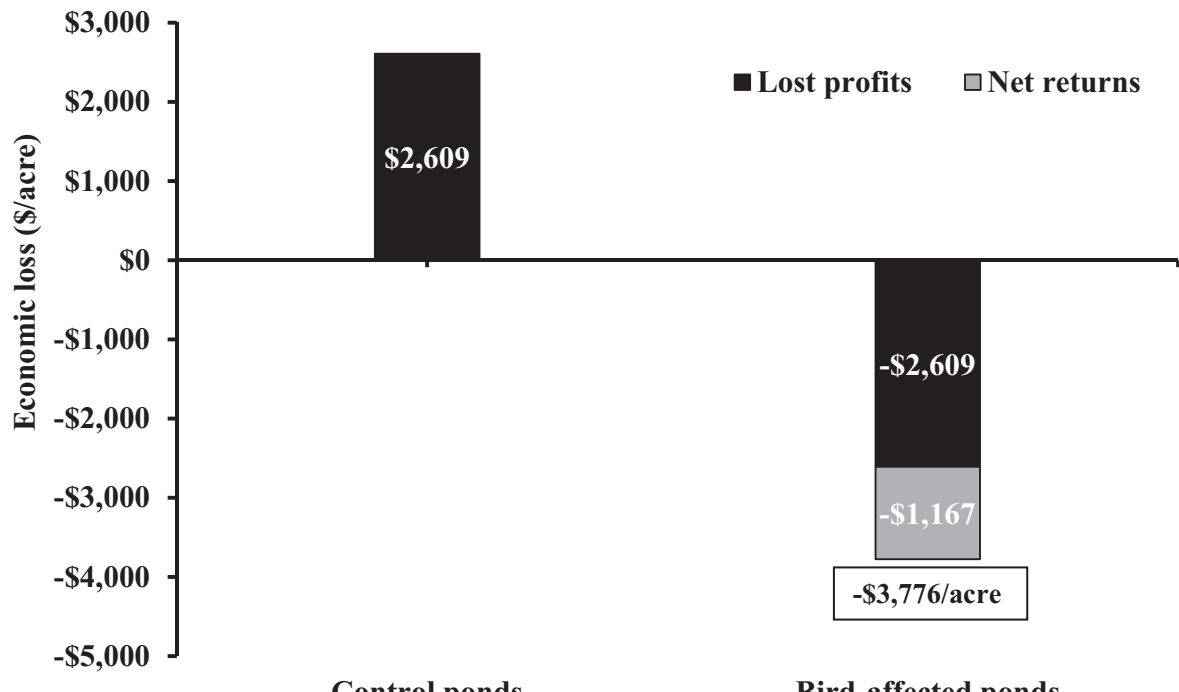

FIGURE 5. Economic losses (\$acre) from bird depredation in intensively aerated ponds, 2017.

greater production from these ponds, typically 12,000 18,000 lb/acre (Bott et al. 2015; Kumar and Engle 2017a; Torrans and Ott 2018), spreads the fixed costs over greater volumes of fish production, thus achieving cost efficiencies. Compared with multiple-batch systems, the breakeven yields that are required to cover the total costs of production in intensively aerated systems are higher (Kumar et al. 2018, 2019, 2020; Engle et al. 2020), causing predation losses to be a greater source of economic risk.
This study documented relative yield losses of $8,889 \mathrm{lb} /$ acre ${ }^{4}$ from bird predation, primarily due to extensive predation from DCCO. The loss in survival that was attributed to predation by DCCO was $42 \%$, which increased the cost of production by $35 \%$ and resulted in negative net

\footnotetext{
${ }^{4}$ Lost revenue (at a fish price of $\$ 1.00 / \mathrm{lb}$ ) was $\$ 8,889 /$ acre. However, true economic losses should account only for lost profits and not lost revenues when data is available (Engle 2010; Asche et al, in press).
} 
returns. However, the result for net economic losses due to bird predation is much higher, as it includes forgone profits that could have been earned in the absence of bird predation. The combined effect of lost profits and negative net returns caused an economic loss of $\$ 3,776 /$ acre from bird predation.

Documented fish losses to piscivorous birds at the TCNWAC facility illustrates the extent of economic damage that can occur at a pond and farm level if only nonlethal harassment techniques are used. In the absence of supplemental lethal control, birds appeared to habituate to nonlethal methods and increase predation. If they were occurring on commercial catfish farms on any given scale, the magnitude of fish losses as reported in this study would be economically detrimental, especially because catfish farms lack the compensatory economic relief programs that are available to other agriculture sectors.

Mitigating fish losses to birds on commercial catfish farms involves several activities such as securing depredation permits from the government, purchase of various bird-scaring devices, and employing manpower and trucks to harass birds from preying fish off farms. Additionally, it consumes significant time, labor, and management away from fish production. The direct losses to bird predation as well as the actual costs of bird control impose a tremendous economic burden on catfish producers (Engle et al. 2020). Different nonlethal harassment methods that are used on catfish operations include frightening strategies, exclusion wirings/nets, and using buffer prey to reduce damage (Mott and Boyd 1995). However, recent studies (Burr 2019; Dorr and Fielder 2017; Hegde and Kumar 2019) suggest these nonlethal-harassment methods are ineffective if they are not used in combination with lethal control measures. These data demonstrate the importance of maintaining bird-depredation orders, issued by the Department of Interior and managed by the U.S. Fish and Wildlife Service, to minimize economic losses on commercial catfish farms that are caused by migratory piscivorous birds.

\section{CONCLUSIONS}

Fish loss to piscivorous birds is a significant economic issue on catfish farms. Documented fish losses from commercial-scale research ponds demonstrate the potential economic impact of piscivorous birds on catfish production if control measures are based solely on nonlethal techniques. The economic losses that are reported in this study from single- and multiple-batch production ranged from $\$ 3,518$ to $\$ 4,060 /$ acre. While these results cannot be extrapolated across the commercial catfish industry, they highlight the fact that, without the lethal take of birds, damages of these proportions on a few ponds on a farm can significantly affect farm profitability. Fish losses to federally protected birds are a regulatory issue, and effective bird-harassment policies are critical to maintaining the profitability of domestic aquaculture. Roost dispersal activities that are coordinated by federal agencies and the timely issue of bird depredation permits are vital for mitigating this persistent and growing problem in the U.S. catfish industry.

\section{ACKNOWLEDGMENTS}

This work was supported by the U.S. Department of Agriculture-National Institute of Food and Agriculture (Hatch Project Accession Number 1013160) and the Mississippi Agriculture and Forestry Experiment Station. The suggestions that were provided by Carole Engle, Paul Zajicek, and three anonymous reviewers are greatly appreciated. Any opinions, findings, conclusions, or recommendations that are expressed in the publication are those of the authors. There is no conflict of interest declared in this article.

\section{ORCID}

Ganesh Kumar (D) https://orcid.org/0000-0003-4765-5306

Shraddha Hegde (iD https://orcid.org/0000-0001-9006-4179

David Wise (iD https://orcid.org/0000-0001-9126-0227

Charles Mischke (D https://orcid.org/0000-0002-3934-9571

Brian Dorr (iD https://orcid.org/0000-0001-6857-8560

\section{REFERENCES}

Asche, F., J. L. Anderson, R. Botta, G. Kumar, E. B. Abrahamsen, L. T. Nguyen, and D. Valderrama. In press. Economics of shrimp disease. Journal of Invertebrate Pathology. Available: https://doi.org/10. 1016/j.jip.2020.107397

Bott, L. B., L. A. Roy, T. R. Hanson, J. Chappell, and G. N. Whitis. 2015. Research verification of production practices using intensive aeration at a hybrid catfish operation. North American Journal of Aquaculture 77:460-470.

Burr, P. 2019. Longitudinal evaluation of habitat use and foraging ecology of piscivorous avian species wintering in the Mississippi Delta. Doctoral dissertation. Mississippi State University, Starkville.

Campo, S. R., and S. Zuniga-Jara. 2018. Reviewing capital cost estimations in aquaculture. Aquaculture Economics and Management 22:72-93.

Christie, T. W. 2019. Predation risk of double-crested cormorants (Phalacrocorax auritus) on commercial catfish production in the Mississippi Delta. Master's thesis. Mississippi State University, Starkville.

Cunningham, F. L., K. C. Hanson-Dorr, L. Ford, D. R. Middleton, A. Crain, L. Durst, C. Ware, M. J. Griffin, C. C. Mischke, X. Wan, and L. A. Hanson. 2020. Environmental factors and animal vector(s) associated with atypical Aeromonas hydrophila abundance and dissemination among Channel Catfish ponds. Journal of the World Aquaculture Society 51:750-762.

DOI (Department of the Interior). 2019. United States Fish and Wildlife Service endangered and threatened species: receipt of recovery permit applications. Federal Register 84:244(19 December 2019):6976269763. 
Dorr, B., and C. R. Engle. 2015. Influence of simulated double-crested cormorant, Phalacrocorax auritus, predation on multiple-batch production of Channel Catfish, Ictalurus punctatus. Journal of the World Aquaculture Society 46:319-327.

Dorr, B., and J. D. Taylor II. 2003. Wading bird management and research on North American aquaculture facilities. Pages 52-61 in K. Fagerstone and G. Witmer, editors. Tenth wildlife damage management conference proceedings. The Wildlife Damage Management Working Group of the Wildlife Society, Fort Collins, Colorado.

Dorr, B. S., L. W. Burger, S. C. Barras, and K. Godwin. 2012a. Economic impact of double-crested cormorant (Phalacrocorax auritus) depredation on Channel Catfish (Ictalurus punctatus) aquaculture in Mississippi, USA. Journal of the World Aquaculture Society 43:502513.

Dorr, B. S., L. W. Burger, S. C. Barras, and K. Godwin. 2012b. Doublecrested cormorant distribution on catfish aquaculture in the Yazoo River basin of Mississippi. Wildlife Society Bulletin 36:70-77.

Dorr, B. S., and D. G. Fielder. 2017. Double-crested cormorants: too much of a good thing? Fisheries 42:468-477.

Dorr, B. S., K. C. Hanson-Dorr, T. L. DeVault, S. C. Barras, and A. Guillaumet. 2014a. Evidence of geographic segregation and densitydependent changes in sex ratios in an abundant colonial waterbird. Integrative Zoology 9:570-582.

Dorr, B. S., J. J. Hatch, and D. V. Weseloh. 2014b. Double-crested cormorant (Phalacrocorax auritus). Page 109 in A. Poole, editor. The birds of North America [online]. Cornell Lab of Ornithology, Ithaca, New York.

Engle, C. R. 2003. The evolution of farm management, production efficiencies, and current challenges to catfish production in the United States. Aquaculture Economics and Management 7:67-84.

Engle, C. R. 2010. Aquaculture economics and financing. WileyBlackwell, Oxford, UK.

Engle, C. R., T. W. Christie, B. S. Dorr, G. Kumar, J. B. Davis, L. A. Roy, and A. M. Kelly. 2020. Principal economic effects of cormorant predation on catfish farms. Journal of the World Aquaculture Society $52: 41-56$.

Engle, C. R., and N. M. Stone. 2013. Competitiveness of U.S. aquaculture within the current U.S. regulatory framework. Aquaculture Economics and Management 17:251-280.

Glahn, J. F., and K. E. Brugger. 1995. The impact of double-crested cormorants on the Mississippi Delta catfish industry: a bioenergetics model. Colonial Waterbirds 18:168-175.

Glahn, J. F., and B. S. Dorr. 2002. Captive double-crested cormorant Phalacrocorax auritus predation on Channel Catfish Ictalurus punctatus and its influence on single-batch cropping production. Journal of the World Aquaculture Society 33:85-93.

Glahn, J. F., and D. T. King. 2004. Bird depredation. Chapter 16 in C. S. Tucker and J. A. Hargreaves, editors. Biology and culture of channel catfish. Elsevier, New York.

Glahn, J. F., D. S. Reinhold, and C. A. Sloan. 2000. Recent population trends of double-crested cormorants wintering in the delta region of Mississippi: responses to roost dispersal and removal under a recent depredation order. Waterbirds 23:38-44.

Glahn, J. F., and A. R. Stickley Jr. 1995. Wintering double-crested cormorants in the delta region of Mississippi: population levels and their impact on the catfish industry. Colonial Waterbirds 18(Special Publication 1): 137-142.

Glahn, J. F., S. J. Werner, T. Hanson, and C. R. Engle. 2002. Cormorant depredation losses and their prevention at catfish farms: economic considerations. Pages 138-146 in L. Clark, J. Hone, J. A. Shivik, R. A. Watkins, K. C. VerCauteren, and J. K. Yoder, editors. Human conflicts with wildlife: economic considerations. Proceedings of the third National Wildlife Research Center special symposium. National Wildlife Research Center, Fort Collins, Colorado.
Griffin, M. J., L. H. Khoo, S. R. Reichley, C. Ware, T. G. Rosser, N. R. Alberson, E. T. Woodyard, L. M. Pote, T. E. Greenway, A. Tiwari, C. C. Mischke, and D. J. Wise. 2018. Encapsulation of Bolbophorus damnificus (Digenea: Bolbophoridae) metacercariae in juvenile Channel Catfish, Ictalurus punctatus, is linked to delayed-onset mortality. Journal of the World Aquaculture Society 49:601-611.

Hanson, T. R. 2019. Catfish processing and feed deliveries. Various months of 2010-2018. Report prepared for the Catfish Institute, Jackson, Mississippi.

Hatch, J. J. 1995. Changing populations of double-crested cormorants. Colonial Waterbirds 18:8-24.

Hegde, S., and G. Kumar. 2019. Economics of bird depredation: a catfish case study. NWAC News 16(1):6-7.

King, D. T. 1995. American white pelicans: the latest avian problem for catfish producers. Pages 31-35 in J. B. Armstrong, editor. Proceedings of the seventh Eastern Wildlife Damage Management Conference. North Carolina Cooperative Extension Service, Raleigh.

King, D. T., J. L. Belant, J. B. Harrel, and J. F. Glahn. 2010. Superabundant food at catfish aquaculture facilities improves body condition in American white pelicans. Waterbirds 33:221-227.

King, D. T., and S. J. Werner. 2001. Daily activity budgets and population size of American white pelicans wintering in south Louisiana and the delta region of Mississippi. Waterbirds 24:250-254.

Kumar, G., and C. R. Engle. 2010. Relative production performance and cost of food fish production from fingerlings of Channel-Blue $F_{1}$ hybrids, Ictalurus punctatus-Ictalurus furcatus, and NWAC-103 Channel Catfish, I. punctatus. Journal of the World Aquaculture Society 41:545-554.

Kumar, G., and C. R. Engle. 2017a. Economics of intensively aerated catfish ponds. Journal of the World Aquaculture Society 48:320-332.

Kumar, G., and C. R. Engle. 2017b. Optimal investment pathways for adopting alternate catfish production technologies: a recursive programming approach. Aquaculture Economics and Management $21: 144-162$.

Kumar, G., C. R. Engle, T. R. Hanson, C. S. Tucker, T. W. Brown, L. B. Bott, L. A. Roy, C. E. Boyd, M. S. Recsetar, J. Park, and L. E. Torrans. 2018. Economics of alternative catfish production technologies. Journal of the World Aquaculture Society 49:1039-1057.

Kumar, G., C. R. Engle, S. Hegde, and J. van Senten. 2020. Economics of U.S. catfish farming practices: profitability, economies of size, and liquidity. Journal of the World Aquaculture Society 51:829-846.

Kumar, G., M. H. Li, D. J. Wise, C. C. Mischke, B. Rutland, A. Tiwari, S. Aarattuthodiyil, M. J. Griffin, L. H. Khoo, B. Ott, L. E. Torrans, and C. S. Tucker. 2019. Performance of Channel Catfish and hybrid catfish in single-batch, intensively aerated ponds. North American Journal of Aquaculture 81:406-416.

Li, M. H., and E. H. Robinson. 2012. Summary of nutrition and feeding studies for pond-raised hybrid catfish. Mississippi Agricultural and Forestry Experiment Station Research Report 24.

Li, M. H., D. J. Wise, G. Kumar, B. G. Bosworth, C. C. Mischke, S. Aarattuthodiyil, W. Rutland, and P. M. Lucas. 2020. Effects of longterm restricted feeding followed by full feeding on growth, processing yield, fillet proximate composition, and economics for market-size hybrid catfish, + Ictalurus punctatus $\times 0^{\star}$ Ictalurus furcatus. Journal of the World Aquaculture Society 51:931-943.

Mott, D. F., and F. L. Boyd. 1995. A review of techniques for preventing cormorant depredations at aquaculture facilities in the southeastern United States. Colonial Waterbirds 18(Special Publication 1):176180.

NABCI (North American Bird Conservation Initiative). 2014. The state of the birds 2014 report. U.S. Department of Interior, Washington, D.C.

Siegel-Causey, D. 1999. The problems of being successful: managing interactions between humans and double-crested cormorants. Pages 
5-14 in M. E. Tobin, editor. Symposium on double-crested cormorants: population status and management issues in the Midwest. U.S. Department of Agriculture, Animal and Plant Health Inspection Service, Technical Bulletin 1879, Washington, D.C.

Stickley, A. R. Jr., and K. J. Andrews. 1989. Survey of Mississippi catfish farmers on means, effort, and costs to repel fish-eating birds from ponds. Proceedings of the Eastern Wildlife Damage Management Conference 4:105-108.

Stickley, A. R. Jr., G. L. Warrick, and J. F. Glahn. 1992. Impact of double-crested cormorant depredations on Channel Catfish farms. Journal of the World Aquaculture Society 23:192-198.

Torrans, L. E., and B. Ott. 2018. Effect of grading fingerling hybrid catfish (o Channel Catfish $\times$ o Blue Catfish) on growth, production, feed conversion, and food fish size distribution. North American Journal of Aquaculture 80:187-192.

Tucker, C. S., D. E. Brune, and L. E. Torrans. 2014. Partitioned pond aquaculture systems. World Aquaculture 6:9-17.

Tucker, C. S., J. A. Steeby, J. E. Waldrop, and A. B. Garrard. 1994. Production characteristics and economic performance for four Channel Catfish, Ictalurus punctatus, pond stocking density-cropping system combinations. Journal of Applied Aquaculture 3:333-352.
USDA (U.S. Department of Agriculture). 2010. Catfish 2010 part II: health and production practices for food size catfish in the United States, 2009. USDA, Animal and Plant Health Inspection Service, Veterinary Services, Center for Epidemiology and Animal Health, 595.0611, Fort Collins, Colorado.

USFWS (U.S. Fish and Wildlife Service). 2020. Draft environmental impact statement for the management of conflicts associated with double-crested cormorants. USFWS, Falls Church, Virginia.

Wires, L. R., F. J. Cuthbert, D. R. Trexel, and A. R. Joshi. 2001. Status of the double-crested cormorant (Phalacrocorax auritus) in North America. Final Report to U.S. Fish and Wildlife Service, Washington, D.C.

Wise, D. J., A. Camus, T. Schwedler, and J. Terhune. 2004. Health management. Pages $482-488$ in C. S. Tucker and J. A. Hargreaves, editors. Biology and culture of the Channel Catfish. Elsevier, Amsterdam.

Wise, D. J., T. R. Hanson, and C. S. Tucker. 2008. Farm-level economic impacts of Bolbophorus infections of Channel Catfish. North American Journal of Aquaculture 70:382-383.

Wywialowski, A. P. 1999. Wildlife-caused losses for producers of Channel Catfish (Ictalurus punctatus) in 1996. Journal of the World Aquaculture Society 30:46-472. 